Wellington contained any application to take up the new or Analytical Engine, which, however, he said "is not only capable of accomplishing all those other complicated calculations which I had intended, but it also performs all calculations which were peculiar to the Difference Engine, both in less time, and to a greater extent : in fact, it completely supersedes the Difference Engine." Six years later, on November 4, 1842, the then Chancellor of the Exchequer wrote saying that he and Sir Robert Peel "both regretted the necessity of abandoning the completion of a machine, on which so much scientific labour had been bestowed."

Electrostatics: The Great Cube at the Royal Institution

IN December 1835 Faraday had begun his researches in electrostatics with some experiments on a large copper vessel, borrowed for the purpose. Not satisfied with this, it occurred to him to use a large paper box or eube big enough for him to get inside; and this, early in January, he set to work to make. "Have been for some days past engaged in building up a cube of 12 feet in the side" he wrote on January 15. "It consists of a slight wooden frame, constituting the twelve linear edges, held steady by diagonal ties of cord ; the whole being mounted on four glass feet, $5 \frac{1}{2}$ inches long, to insulate it. The sides, top and bottom are covered in with paper". The frame was also strengthened with ties of copper wire, which, with some slips of tin foil pasted on the inside, served to conduct electricity to all parts of the paper covering. "The whole stands in the Lecture room. . . The cube rises in the middle of the room above the level of the bottom of the gallery, and appears of enormous size".

The cube was electrically charged from a frictional machine until sparks flew off at the corners; and with it, Faraday confirmed and extended the observations he had made with the copper vessel. The whole of the electricity resided on the outside surface. An insulating stool was brought up immediately under the bottom of the cube, so as to provide a firm platform and yet preserve the insulation. "I now went inside the cube, standing on the stool, and Anderson worked the machine until the cube was fully charged, and he continued working the machine. I could by no appearance find any traces of electricity in myself or the surrounding objects. I could not affect the gold leaf electrometer within". Delicate electrometers, candle flames and other means of detection were tried, but from no point inside could any evidence of electrical charge be obtained. "The electrification without produced no consequent effects within".

\section{Procedure in Scientific Societies}

ON January 16, 1836, The Times published a letter from "Observator" which said : "It will not, I hope, be considered as improper to respectfully to call the attention of presidents and secretaries to an evil of considerable magnitude, which has crept into the public proceedings of some of our scientific bodies of late years-I mean the very low tone in which announcements are often made from the chair, and papers read by the secretaries. . . . One would be tempted to believe, indeed, that an idea of dignity is sometimes connected with inaudibility. . . . Let, however, a president or secretary only consider himself as addressing the distant part of the persons present and the evil will be remedied. . . ."

\section{Societies and Academies}

\section{EDINBURGH}

Royal Society, December 2. J. WeIR and D. LEITCH : Zonal distribution of the non-marine lamellibranchs in the coal measures of Scotland. All zones from ovalis to tenuis are represented in the Scottish Coal Measures, although they cannot all be delimited. The Productive Coal Measures fall within the ovalis, modiolaris and lower similis-pulchra zones, and are therefore homotaxially equivalent to the lower part of the Middle Coal Measures of Lancashire. In the Central Coalfield the boundary between ovalis and modiolaris zones is taken at the Kiltongue Musselband, and between modiolaris and similis. pulchra zones at the Musselband Coal. Correlations between Central, Douglas and Ayrshire coalfields are deduced. S. Chapman : The lunar atmospheric tide at Glasgow. Reasons are given for believing that the lunar hourly inequalities of barometric pressure at Glasgow recently determined by Robb and Tannahill are substantially not of lunar origin at all (see NATURE, Nov. 16, p. 801). An earlier determination of the lunar atmospheric tide at Glasgow made in 1926 by Robb is now published with his permission, and appears to be a true lunar effect. It indicates that at Glasgow the lunar atmospheric tide is abnormally small for the latitude; the phase seems normal, and corresponds to a lag of high tide in the atmosphere of about one hour after lunar transit. ENID CHARles: The effect of present trends in fertility and mortality upon the future population of Scotland and upon its age composition. Excluding the effects of migration, estimates of the population of Scotland during the next hundred years have been made on two assump. tions, $(a)$ that fertility and mortality remain at their present lovel, and $(b)$ that they continue to decline at the rate shown in the past decade. According to (a), the population will begin to decline slowly about 1970 , being 94 per cent of its present size in a hundred years. According to $(b)$ the population will begin to decline about 1950 and thereafter will diminish rapidly, being 19 per cent of its present size in a hundred years. The effects of past declining fertility and of present low fertility will be seen in a continually decreasing proportion of children and increasing pro. portion of persons aged sixty years and more. The excess of females due to war losses will be replaced by an excess of males in 1960 by both estimates. In fifty years the increasing proportion of the older age groups will result in a higher crude death rate, between 18 and 21 per thousand. A. C. AITKEN and H. T. GONIN : Fourfold sampling with and without replacement. The correlation is examined of characters in a sample drawn at random from a limited population, the individuals of which are classed in four categories, as possessing two char. acters or their alternatives. In the cases both of replacement and of non-replacement of sampled individuals, the probability is found to be expressible as a terminating series in orthogonal polynomials. These are briefly studied, and applications are made to problems of regression and moments.

\section{PARIS}

Academy of Sciences, December 9 (C.R., 201, 11571232). The president announced the deaths of Charles Richet and Henri Jumelle. Marin Molliard: The effect of an enrichment of the atmosphere in 
oxygen on the devolopmont of plants. Description of experiments on the radish and on a mould, Sterigmatocystis nigra. Increase in the proportion of oxygen slows down the development, and in the case of the radish, leads to a loss in dry weight. AlexANDRE GuiluIERmoND : The sexuality of the yeasts and on the relations of these fungi with the Exoasceæ. Georges PóLYA : A general combinatory problem on groups of permutations, and the calculation of the number of isomers of organic compounds. Lucres GODEAUX : Involutions of the second order belonging to certain algebraical varieties of three dimensions. Daniel Barbier and VICTOR MaItre: A new method for the study of the absorption of light in interstellar space. RENÉ LUCAS: The propagation of ultra-sounds in liquid media. Claude CHarmetANT : The electrolysis of the bromides and iodides of zinc, nickel and cobalt in mixtures of water and ethyl alcohol. MLle. Marguerite QuINTIN : The mechanism of hydrolysis in solutions of the salts of the heavy metals. The study of the hydrolysis of the salts of bivalent metals leads to a simple relation, choosing the activity of the metallic cation and that of the hydrogen ion as variables. This would appear to point to the fact that the first stage of the hydrolysis is the formation of a complex ion. HENRI TrICHé : Contribution to the study of the structure of alloys by means of spectrography. By a suitable preparation of the alloy, it is possible to make a qualitative (for some constituents quantitative) analysis for impurities without the necessity of isolating them. Choong Shin-Praw: The emission spectrum of tellurium oxide, TeO. Jean Paul Mathmev: The absorption, optical activity and configuration of mineral complex compounds. Lours LEPRINCERINGUET : The sign and the nature of the ultrapenetrating particles of the cosmic radiation. Study of the particles in a Wilson chamber placed in a powerful magnetic field and after filtration through $7 \mathrm{~cm}$. of lead. The energy of such particles is not less than 700 million electron-volts. Positively and negatively charged particles are present, those with positive charge predominating. NÉdA MARINEsco : The deflagration of explosive substances by ultrasounds. Description of experiments showing how ultra-sounds can be used to explode nitrogen iodide, silver fulminate and a number of powders of the Berthollet type. Paul Corriez: X-ray diagrams of sugar charcoal subjected to different thermal treatments. Various specimens of sugar charcoal, after heating to temperatures between $1,000^{\circ} \mathrm{C}$. and $2,000^{\circ} \mathrm{C}$., never give an $\mathrm{X}$-ray diagram identical with that of natural graphite, but, as the temperature is increased, the lattice distance diminishes and approaches that of graphite. ANDRÉ MrCHeL and Georges Chaudron: The study of stabilised cubic ferric oxide. Jean Bureau : The system water lithium nitrite : the hydrate $\mathrm{LiNO}_{2}, 1 \cdot 5 \mathrm{H}_{2} \mathrm{O}$. ERNEST KAHANE and $T$. Tomesco: The action of perchloric acid on iodine and on iodine derivatives. The determination of iodine in organic substances. Study of the conditions under which the equation $7 \mathrm{HClO}_{4}+4 \mathrm{KI}=4 \mathrm{HIO}_{3}+3 \mathrm{HCl}+4 \mathrm{KClO}_{4}$ is strictly fulfilled. JEAN AMIEL: The preparation and properties of double chlorides and bromides of bivalent nickel and organic bases. ANTOINE WILLEMART: Researches on the dissociable anthracene oxides : the influence of naphthyl groups. Paul Gaubert : The microchemical determination of cholesterol, urea, glycerol, etc., based on the formation of liquid crystals. Gilbert Mathreu : The different coal formations of tho Bassin de Vouvant (Vendée et Deux-Sèvres). Georases Dentzot: The constitution of the vals of the Loire and on the meaning of the hillocks not covered by floods. M. and MME. Fernand Moreau : The cytological phenomena of the development of the egg and of fertilisation in fungi of the Saprolegnite group. MARC SIMoNeT : Contributions to the cytological and genetic study of some Agropyrum. ROBERT BONNET and RAYMOND JACQUOT: The glucidic metabolism of Sterigmatocystis nigra is a function of the nitrogen source of the culture medium. EMILE Michel-Durand: The metabolism of phosphorus in the leaves of some plants with persistent foliage during change to yellow. P. Nottin and A. Daron : The examination of wheats and flours by means of the Chopin extensimeter. The importance of working with a paste with a definite proportion of water is emphasised. Philippe Joyet-Lavergne : The detection of vitamin $\mathrm{A}$ in the red blood corpuscles of the blood of vertebrates. ANToINe MAGNAN and HENRY Girerd : The determination of the pressures on the wings of a pigeon during taking off, horizontal flight and landing. Lours Bounoure : An experimental proof of the role of the germinal determinant in the russet frog. Georges BLANC, M. Noury and M. Baltazard : Precedence and pre-immunity in the course of exanthematic typhus and in the course of hidden infection by bile-treated virus. RAYMOND Moussu: The physiological prevention of epizootic abortion in cattle. WLADISLAS KOPACZEWSKI : The seric proteins in cancer.

\section{LENINGRAD}

Academie des Sciences $(C . R ., 3$, No. 6, 1935). G. A. KruTkow : Further notes on the Brownian movement of a particle with axial symmetry. L. N. SRETENSKIJ : A problem of minimum in the theory of ships. P. A. WALther : Hodograph of an ideal hydraulic girder. N. V. KREMENEvSKIJ : Absorption spectrum of lead vapour in the Schumann region. P. D. DANKov: Heterogeneous catalysis theory. W. A. Fabrikant and A. S. Kanel: Influence of pressure on the radiation emitted by cadmium vapour. W. W. ShulejknN : On the 'voice' of the sea. The air passing over a disturbed surface of sea develops oscillations which may spread over great distances and be observed by means of a balloon filled with hydrogen which, by resonance, produces a sound effect. These facts may serve as a basis for storm warnings. B. M. DuBININ Action of isobutylene on methyl phenol ether and the structure of pseudo-butyl-methyl phenol ethers. N. A. and V. A. Preobrazhenski $J$ and A. M. PouJakova: Alkaloids obtained from the leaves of jaborandi. The synthesis of the alkaloid pilo. carpidine. S. BaLACHovskIJ : The reed (Phragmites communis) as a source of vitamin C. V. S. SADIKOv and E. V. LINDQUIST-RYsakova : Acid autoclaving of blood albumin at $220^{\circ}$. L. M. Dorochov: An instrument for the determination of humidity in an air current during physiological investigations. A. J. Ivanov: Forms of the genus Budytes. L. A. Portenko: A new form of the willow-wren from north-eastern Siberia: Phylloscopus trochilus expressus, subsp.n. Known geographical forms are revised. R. J. BeLKIN and A. A. WoITKEwITSCH : Influence of quinine on the realisation of morphogenetic action of the pituitary hormone. 